\title{
The Influence of Organizational Internal Politics on Community Equity Satisfaction in the Aceh Singkil Ethnic
}

\author{
$1^{\text {st }}$ Rahmi Suci, $2^{\text {nd }}$ Dasman Lanin, $3^{\text {rd }}$ Boni Saputra \\ \{rahmisuci96@gmail.com ${ }^{1}$, dasman@fis.unp.ac.id ${ }^{2}$, bonisaputra@ fis.unp.ac.id ${ }^{3}$ \} \\ Master of Public Administration, Faculty of Social Sciences, Universitas Negeri Padang, Padang, \\ Indonesia
}

\begin{abstract}
This study aims to analyze the influence of internal organizational politics on community equity satisfaction in Aceh Singkil Ethnicity. This research approach uses quantitative methods. The population in this study was the Aceh Singkil ethnic community, with a sample of 220 samples determined using the Slovin formula with an error rate of 0.05. The was determined using the Accidental sampling technique. Data were collected using a questionnaire distributed to respondents with measurements using a linkert scale using regression analysis techniques. This study shows the results of the influence of organizational politics on community equity satisfaction in the Aceh Singkil ethnic group with a significant amount of 0.005 .
\end{abstract}

Keywords: Organizational Internal Politics, Equity Satisfaction, Aceh Singkil Ethnic.

\section{Introduction}

Public service that satisfies the community is a necessity for public accountability for the government. The condition of public services felt by almost all people (regions) is still not satisfactory[1]. Public satisfaction is the main factor that must be considered by public service providers, because community satisfaction will determine the success of the government in providing public services. The definition of public satisfaction is often equated with the definition of customer satisfaction or customer satisfaction, the difference is in the subject and object of the service. Service providers in public services are employees of government agencies who carry out public service tasks in accordance with mandated laws and regulations and service recipients are individuals, communities, government agencies and the business world, who benefit from an activity to provide public services.

[2] Pasal 1 paragraph (1) Law no. 25 of 2009 concerning Public Services, public services are activities or series of activities in order to fulfill service needs in accordance with the laws and regulations for every citizen and resident for goods, services, and / or administrative services provided by public service providers. Next [3] The quality of public services is the totality of the ability of service providers to provide services to products (goods or services) and administrative services to customers or the public, which can meet needs and can provide satisfaction to customers based on conformity with the expectations and reality received by 
customers or society. . [1] Satisfaction or satisfaction has become a research concept that began to develop in the public sector, although in the private sector it has been developing relatively long and fast. In the private sector the concept of customer satisfaction has become a major measure for a quality of service itself. With the growing development of ideas or innovations initiated by the Ministry of Administrative Reform and Bureaucratic Reform in government or public sector services, the responsibility is not only to the internal public organization but also to external organizations, in this case the community, public and citizens. . The government has changed the paradigm from state-oriented to public-oriented, which initially applied the concept of serving its master, turned into a servant to the community, from being a servant of the state to being a public servant, which resulted in creating power, trust and public voice or political participation.

[4] Operationally, satisfaction is a variable that involves detailed information about the views of the community (citizen) with various public services at the national, regional and community levels. If the expectations of the community are higher than the reality they are experiencing, then the community will feel dissatisfied (dissatisfaction), on the contrary, if the expectations of the community are the same or lower than the reality they are experiencing, the community will be satisfied (satisfaction) [5]. [6] On Generally, someone's hope is a feeling or belief about what he will receive if he buys or consumes a product (goods or services).Satisfaction is also one of the achievements of public services carried out by the government, in addition to creating trust in governance, voice and political efficacy, political participation, and also at macro level is the welfare of the community.Community satisfaction or what is called external customer satisfaction is the independent variable in this study and focuses on the Aceh Singkil community as local wisdom, because local wisdom is an aspect of conflict peace in conflict management. [7] Dasman \& Syamsir found a model for a local government service for customer satisfaction based on TQM (Total Quality Management). The model has six service transaction variables: (1) Delivery, (2) Timeliness, (3) Professionalism, (4) Staff Attitude, (5) Available Information, and (6) Organizational Politics (the internal political state of the organization).

Aceh Singkil Regency is one of the districts in Aceh Province which is a division of South Aceh Regency and part of its territory is in the Gunung Leuser National Park area. This district consists of two regions; namely land and islands. Aceh Singkil Regency is the only underdeveloped and poorest area in Aceh Province which was determined by President Joko Widodo through Presidential Regulation Number 131 of 2015 concerning Stipulation of Underdeveloped Areas in 2015-2019. The people of Aceh Singkil think that government services to the community are dead. This is illustrated by the coffin stretcher that the demonstrators carried during the demonstration which was recorded 27 times in the 2018-2019 period. The residents of Kota Baharu Subdistrict demand development injustice, starting from the health sector, educational facilities and construction of infrastructure and facilities. The Indonesian Ombudsman representative of Aceh found the cause of the inadequate public service of the Aceh Singkil Regional Hospital, the cause was due to a lack of human resources[8].

This is one of the factors that encourages researchers to focus this research on the influence of internal organizational politics on equity satisfaction in the Aceh Singkil ethnic group. The formulation of the problem in this study is whether the internal political atmosphere of the organization influences or becomes a determining factor for public satisfaction with public sector services? 


\section{Methodology}

This study uses a quantitative approach associative. The dependent variable (Y) of this study is the satisfaction of public equity with internal organizational politics as the independent variable (X). The research location is located in Aceh Singkil Regency as one of the ethnic groups on the island of Sumatra. The study population was all the people of Aceh Singkil Regency. There were 220 respondents or samples in this study. The research sample was obtained using Accidental Sampling technique using the Slovin formula with an error rate of 0.05. Data were collected using a questionnaire or questionnaire distributed to respondents. The instrument in this study was a questionnaire based on the linkert scale used to measure the attitudes, opinions and perceptions of a person or group about social phenomena or research variables.[10]. Then the data collected were analyzed using the SPSS version 25 application with a simple regression analysis method. The form of the regression equation in this study is as follows:

$$
\alpha+\beta i X 1=\mathrm{Y}
$$

Information :

$\alpha \quad=$ Constant

$B i \quad=$ Organizational internal political regression coefficient

$X 1 \quad=$ Satisfaction of community equity

The hypothesis of this study can be formulated as follows:

$\mathrm{Ha}$ : There is a significant influence between the internal politics of the organization on the satisfaction of public equity in the Aceh Singkil ethnic group

$\mathrm{HO}$ : There is no significant influence between the internal politics of the organization on the satisfaction of community equity in the Aceh Singkil ethnic group

This study seeks to show the influence of internal organizational politics on community equity satisfaction in Aceh Singkil ethnicity, which is described as follows:

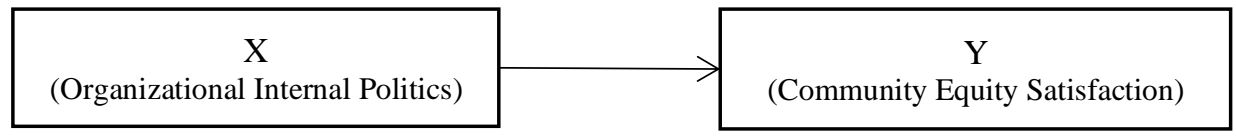

Image 1. conceptual framework

\section{Results and Discussion}

\section{Research Demographic Characteristics}

The purpose of research demographics is descriptive analysis conducted on the respondents studied. The characteristics of the respondents in this study can be described as a whole in the following table : 
Table 1. Research Demographic Characteristics.

\begin{tabular}{|c|c|c|c|c|c|}
\hline Gender & & Age & & Education & \\
\hline Man & 96 & $<20$ & 55 & SD / equivalent & 15 \\
\hline \multirow[t]{4}{*}{ Women } & 124 & $21-30$ & 98 & $\begin{array}{l}\text { Junior high school / } \\
\text { equivalent }\end{array}$ & 15 \\
\hline & & $31-40$ & 30 & $\begin{array}{l}\text { Senior high school } \\
\text { / equivalent }\end{array}$ & 93 \\
\hline & & 41-50 & 23 & College & 91 \\
\hline & & $>50$ & 14 & Others & 6 \\
\hline TOTAL & 220 & Total & 220 & Total & 220 \\
\hline
\end{tabular}

Based on the table above, it can be seen that the dominant respondent is female as many as 124 people. Of the 220 respondents all came from the Aceh Singkil ethnicity, with a dominant age range ranging from 21-30 years as many as 98 people. The dominant education of respondents is high school graduates / equivalent as many as 93 people.

\section{The Influence of Organizational Internal Politics on Community Equity Satisfaction}

Public equity satisfaction as the dependent variable which is confirmed by the internal politics of the organization as the independent variable. The data obtained in the field through a questionnaire are then processed by a simple regression analysis mechanism, and the following results are obtained:

Table 2. The Influence of Organizational Internal Politics on Community Equity Satisfaction in Aceh Singkil Ethnic.

\begin{tabular}{lcccc}
\hline \multicolumn{4}{c}{ Model Summary } \\
Model & $\mathrm{R}$ & $\mathrm{R}$ Square & $\begin{array}{c}\text { Adjusted R } \\
\text { Square }\end{array}$ & $\begin{array}{c}\text { Std. Error of the } \\
\text { Estimate }\end{array}$ \\
\hline 1 & $.187 \mathrm{a}$ & .035 & .031 & 2,671 \\
\hline a. Predictors: (Constant), Internal Politics \\
\hline \multicolumn{5}{c}{ Source: Processed data for 2020 }
\end{tabular}

The table above shows the value of R 0.187 , R Square 0.035 , and Adjusted R Square 0.031 . Thus, the internal political organizational variables contributed $3.5 \%$ to the satisfaction of community equity in the Aceh Singkil ethnic group.

Table 3. Anova

ANOVAa

\begin{tabular}{llrrrrr} 
Model & & Sum of Squares & Df & Mean Square & F & Sig. \\
\hline \multirow{2}{*}{1} & Regression & 56,610 & 1 & 56,610 & 7,935 & $.005 \mathrm{~b}$ \\
\cline { 2 - 7 } & Residual & 1555,185 & 218 & 7,134 & & \\
\cline { 2 - 6 } & Total & 1611,795 & 219 & & & \\
\hline
\end{tabular}

a. Dependent Variable: Community Equity Satisfaction

b. Predictors: (Constant), Internal Politics

Source: Processed data for 2020 
From the table above, it can be seen that the calculated $F$ value of 7.935 with a significance level of $0.005(0.005<0.05)$, which means that the regression model can be used to predict participatory variables or in other words, there is an influence of internal political variables $(\mathrm{X})$ on the satisfaction variable of public equity $(\mathrm{Y})$.

Table 4. Coefficients

\begin{tabular}{|c|c|c|c|c|c|c|}
\hline \multicolumn{7}{|c|}{ Coefficientsa } \\
\hline \multirow{2}{*}{\multicolumn{2}{|c|}{ Model }} & \multicolumn{2}{|c|}{ Unstandardized Coefficients } & \multicolumn{3}{|l|}{$\begin{array}{l}\text { Standardized } \\
\text { Coefficients }\end{array}$} \\
\hline & & B & Std. Error & Beta & $\mathrm{t}$ & Sig. \\
\hline 1 & (Constant) & 11,776 & .739 & & 15,933 & .000 \\
\hline & Polinternal & .111 & .039 & .187 & 2,817 & .005 \\
\hline
\end{tabular}

a. Dependent Variable: Community Equity Satisfaction

Source: Processed data for 2020

Based on the table above, it is known that the constant value (a) is 11.776 , while the internal political value of the organization (b / regression coefficient) is 0.111 . So that the regression equation can be written as follows:

$$
\begin{gathered}
a+b X=Y \\
11.776+0.111 X=Y
\end{gathered}
$$

This equation can be translated into the consistent value of the public equity satisfaction variable is 11,776 . The $\mathrm{X}$ regression coefficient is 0.111 which states that every $1 \%$ addition of the internal political value of the organization, the participation value increases by 0.111 . This regression coefficient is positive, so it can be said that the direction of the influence of the variable $\mathrm{X}$ on $\mathrm{Y}$ is positive. The significance value obtained is $0.005(0.005<0.05)$, which means that the internal political variables of the organization have an effect on the satisfaction of public equity in the Aceh Singkil ethnic group. If seen from the value of t count 2.817> 1.970 ( $t$ table), this means that variable $\mathrm{X}$ has an effect on variable $\mathrm{Y}$ because $\mathrm{t}$ is greater than $\mathrm{t}$ table.

\section{Finding and Discussion}

The results of data processing show The internal politics of the organization has an influence of $3.5 \%$ on the satisfaction of community equity in the Aceh Singkil ethnic group with a significance of 0.005 . This means that the results of this study are at the $95 \%$ confidence level and the effect is positive.This is evidenced by the results of processed data using the help of SPSS software version 25, that it is found that the R Square value is 0.035 and when viewed from the $t$ value it shows $t_{\text {count }}>t_{\text {table. }}$. So that hypothesis a $(\mathrm{Ha})$ is accepted.The results of this study support the research previously conducted by [1] which states that one that affects external customer equity satisfaction is the internal politics of the organization. By utilizing existing culture and values, it will form a public administration that has character and uniqueness based on local wisdom. Even the values that exist in society often have a positive influence on development efforts if they understand and are good at using them [10]. 
From the findings in the field, it was also found that Aceh has Mukim which is marked by the issuance of Law no. 11 of 2006 concerning the Government of Aceh. Mukim is a government institution that was born from special autonomy which has been transformed from an informal institution to a formal institution. The formation of a mukim government system in Aceh in order to realize these ideal values. The position of the mukim government which is below the sub-district and above the gampong government becomes a unique government structure recognized by the state and only applies in Aceh.[11]. The institutional dynamics in the past that were relatively able to regulate the sociocultural life of the community fairly and wisely are considered relevant to be applied in today's life.[12].

The Aceh Singkil ethnic community is very thick with Islam and use deliberation in decision making. In terms of conveying their voice or aspiration, Mukim is the mouthpiece of the government. The existence of Mukin in the government structure between the Gampong and the District greatly influences in terms of providing input, suggestions, or criticism from the community for the District Government and so on in order to provide public services according to community needs. Research that supports the efficacy of ethnic values includes [8] who found that people in all nagari in Minangkabau feel more happy if they are managed with ethnic cultural valuescompared to top-down management by the government. Furthermore, [9] shows that identity leadership tends to have a positive impact as the foundation for the initial commitment and capabilities of village leaders and managers. Appreciation for the demands of local identity and culture at the rural level as social capital in government management needs to be developed as a model.

\section{Conclusion}

After conducting research, data processing and discussion, so that this study can be concluded that the internal politics of the organization has an effect on the satisfaction of public equity in the Aceh Singkil ethnic group with an influence of $3.5 \%$ with a significant 0.005 and the effect is positive. Through this research, it is also suggested that the Aceh Singkil district government consider the internal politics of the organization in carrying out public services. In order for community satisfaction with the services provided to be fulfilled, it means that the services provided by the Aceh Singkil Regency government are in accordance with the expectations or expectations of the community. Providing services to the community must also include local values so that the services provided are in accordance with community needs.

\section{Acknowledgments}

This article is part of the research conducted by Prof. Dasman Lanin, Ph.D in 2020. The author would like to thank Padang State University especially the Institute for Research and Community Service, Padang State University. The author also expresses his gratitude to the government and the people of Aceh Singkil Regency who have been willing to become respondents in this study. And also the author's thanks to the research team, so that this research can be completed on time. 


\section{Reference}

[[1] D. Lanin and Syamsir, "Regional Government Service Model that Satisfies Internal and External Customers based on Total Quality Management; at Padang Panjang Hospital, "Padang, 2017.

[2] MH and HAMR Indonesia, Republic of Indonesia Law No. 25 of 2009 concerning Public Services. 2009.

[3] A. Duriat and R. Vaughan, "The Effect of E-Ktp Service Quality on Community Satisfaction in Kramatmulya District," Policy. J. Science Adm., Vol. 11, no. 1, pp. 1827, 2020, doi: 10.23969 / policy.v11i1.2231.

[4] E. Vigoda-Gadot, "Citizens' perceptions of politics and ethics in public administration: A five-year national study of their relationship to satisfaction with services, trust in governance, and voice orientations," J. Public Adm. Res. Theory, vol. 17, no. 2, pp. 285-305, 2007, doi: 10.1093 / jopart / muj018.

[5] LR Aritonang, Customer Satisfaction: Measurement and Analysis with SPSS. Jakarta: Gramedia Pustaka Utama, 2005.

[6] A. Mayasari, "Analysis of the Influence of Service Quality on Community Satisfaction in Paulan Village, Colomadu, Karanganyar," J. Ekon. Sharia, vol. 3, no. 2, 2020.

[7] W. Astuti, D. Lanin, and Syamsir, "The Effect of Employee Satisfaction on Service Quality Through Delivery and Professionalism in Labor and Industrial Agency of Padang City," in Proceedings of the International Conference On Social Studies, Globalization And Technology (ICSSGT 2019 ) The, 2020, vol. 458, no. Icssgt 2019, pp. 40-50, doi: 10.2991 / assehr.k.200803.006.

[8] D. Rosadi, "These are the findings of the Ombudsman the cause of the inadequate service at the Aceh Singkil Regional Hospital," tribunnews.com, Aceh, 2018.

[9] J. Ahmad, Public Administration Research Methods. Yogyakarta: Gava Media, 2015.

[10] Anismar, "MODEL OF ISLAMIC TOURISM IN SINGKIL ACEH DISTRICT," J. Journalism, vol. 9, no. 1, pp. 84-92, 2019.

[11] M. Manalu, HT Nasution, and I. Nasution, "Capacity Building of Village Government Officials in Aek Korsik Village," Perspective, vol. 7, no. 2, p. 55, 2018, doi: 10.31289 / perspective.v7i2.2530.

[12] Azmi, H. Kusmanto, and Isnaini, "The Effectiveness of the Role of Mukim in the Government System in Aceh Singkil District," J. Ilm. Masters Adm. Public, vol. 1, no. 1, pp. 11-21, 2020.

[13] D. Lanin, "Decentralization Policy and Breeding of Cultural-Ethnic Values in the Bureaucracy (Case: Nagari Automation Model in West Sumatra)," J. Ilmu Adm. and Organs. Business and the Bureaucracy, vol. 14, no. 1, 2006.

[14] D. Lanin, "Local Governance Management in West Sumatra: A Reinforcement Model of Identity Leadership and Culture on Rural," DEMOCRASI, vol. 7, no. 1, pp. 31-50, 2008. 